\title{
OPTIMIZATION OF ABRASIVE WEAR PERFORMANCE OF PM VANADIS 6 TOOL STEEL USING TAGUCHI APPROACH: A STATISTICAL STUDY ON THE EFFECTS OF HEAT TREATMENT AND TESTING CONDITIONS.
}

\author{
${ }^{1}$ Venu YARASU, ${ }^{1}$ Peter JURČI, ${ }^{2}$ Jakub HORNIK \\ ${ }^{1}$ Faculty of Material Sciences and Technology of the STU in Trnava, Trnava, Slovakia, EU, \\ venu.yarasu@stuba.sk \\ ${ }^{2}$ Czech Technical University in Prague, Faculty of Materials Engineering, Prague, Czech Republic, EU, \\ Jakub.Hornik@fs.cvut.cz
}

https://doi.org/10.37904/metal.2021.4167

\begin{abstract}
The friction and wear behavior of cold-work tool steel materials is a subject of interest to researchers and tribologists. Both friction and wear are the key factors affecting the life of a tool. This study investigates the abrasive wear performance of Vanadis 6 material against the sintered alumina $\left(\mathrm{Al}_{2} \mathrm{O}_{3}\right)$ counterpart. The friction and wear tests were performed on a pin on disk tribometer at room temperature. The design of experiment approach based on the Taguchi methodology was used for experimentation and Taguchi's L18 orthogonal array was used based on the mixed levels $\left(2^{\wedge 1} 3^{\wedge}\right)$ of the control factors viz., tempering temperature, subzero temperature, sliding velocity, and load. Further, the ANOVA technique was used to identify the significant factors and their contribution to the tribological performance of Vanadis 6 . It is evident that the load is the most significant parameter that affects both the mean friction coefficient and wear rate followed by tempering temperature. Taguchi analysis revealed that using a tempering temperature of $170 \mathrm{C}^{\circ}$, the subzero temperature of $-140^{\circ} \mathrm{C}$, the sliding velocity of $18.85 \mathrm{~cm} / \mathrm{s}$, and $10 \mathrm{~N}$ normal load gives the optimum setting for the mean coefficient of friction and a tempering temperature of $170 \mathrm{C}^{\circ}$, sub-zero temperature of $-140^{\circ} \mathrm{C}$, sliding velocity of $6.4 \mathrm{~cm} / \mathrm{s}$, and $1 \mathrm{~N}$ normal load gives the optimum setting for wear rate.
\end{abstract}

Keywords: Vanadis 6 steel, sub-zero treatment, taguchi method, dry sliding wear test, analysis of variance

\section{INTRODUCTION}

Vanadis $6, \mathrm{Cr}-\mathrm{V}$ tool steel is a special wear resistance steel manufactured by powder metallurgy (PM) route. Due to its superior wear resistance and compressive strength, it is popular in cold-work applications [1]. The main alloying elements of Vanadis 6 are chromium and vanadium. Chromium produces less stable carbides whereas vanadium forms very stable MC-carbides. Due to the small size and high thermal stability of these MC-carbides Vanadis 6 steel is resistant to grain coarsening during austenitization and yields favorable mechanical properties after the heat-treatment [2].

The sub-zero treatment (SZT) is an add-on process to conventional heat treatment ( $\mathrm{CHT}$ ) of $\mathrm{Cr}-\mathrm{V}$ ledeburitic tool steels. In this process, the material is immersed into suitable cryogenic media immediately after the quenching, for a suitable time and re-heated to room temperature followed by a tempering process [3]. Many researchers have studied the effects of SZTs on the performance of AISI D2 [4-6], AISI D3 [7], and AISI D6 [8] chromium ledeburitic steels, and reported significant improvements of wear performance over conventional 
heat treatment. Sobotova et al. [9] investigated the wear performance of SZT Cr-V ledeburitic steel after tempering at the maximum secondary hardness temperature and found that the wear performance was improved. Jurci et al. [10] studied the hardness response at different sub-zero temperatures for instance, -140, -196 , and $-269^{\circ} \mathrm{C}$ including both low and high tempering temperatures and reported significant hardness improvement for SZT at $-140^{\circ} \mathrm{C}$ in contrast with other SZTs. Although the tribological performance of cold-work tool steels have been investigated and reported, yet optimization of wear performance of $\mathrm{Cr}-\mathrm{V}$ tool steel with different factors has not been reported. Having said that, this study investigates the wear behavior of Vanadis 6 against alumina counterpart $\left(\mathrm{Al}_{2} \mathrm{O}_{3}\right)$ considering effective factors such as sub-zero temperature, tempering temperature, load, and sliding velocity.

This investigation uses the Taguchi approach to optimize the friction coefficient and wear. Further, statistical methods were implemented to study the contributions of selected controlled factors on the friction and wear properties.

\section{METHODOLOGY OF RESEARCH}

\subsection{Material and processing}

PM ledeburitic steel Vanadis 6 was used in this experimental study with nominal composition of (in wt.\%) $2.1 \% \mathrm{C}, 1.0 \% \mathrm{Si}, 0.4 \% \mathrm{Mn}, 6.8 \% \mathrm{Cr}, 1.5 \% \mathrm{Mo}, 5.4 \% \mathrm{~V}$ and $\mathrm{Fe}$ as balance. The steel was delivered in soft annealed condition, with a hardness of $284 \mathrm{HV} 10$.

Plate-like samples with dimensions of $30 \times 30 \times 6 \mathrm{~mm}$ were machined, fine grinded and finished up to the surface roughness of $\mathrm{Ra}=0.04 \mu \mathrm{m}$. After that, they were subjected to various regimes of heat treatment, Table 1. Conventional heat treatment $(\mathrm{CHT})$ comprised the heating up to the austenitizing temperature $\left(1050^{\circ} \mathrm{C}\right)$ in a vacuum furnace, holding at the final temperature for $30 \mathrm{~min}$. and nitrogen gas quenching (5 bar pressure). After that the samples were divided into three batches, and were moved to cryogenic system where they were cooled down to pre-determined sub-zero treatment temperature $\left(-75,-140\right.$, and $\left.-196^{\circ} \mathrm{C}\right)$, at the cooling rate of $1^{\circ} \mathrm{C} / \mathrm{min}$., stored there for $17 \mathrm{hrs}$, and then re-heated to the room temperature. After that, they were tempered. Tempering treatment consisted of two cycles, each of them carried out for $2 \mathrm{hrs}$. After the tempering, the material was air-cooled. Finally, all the specimens were polished up to the mirror finish, by a set of abrasive papers (in grit order 180,320, 600 and 1200), and polished with 9, 6, and $3 \mu \mathrm{m}$ diamond suspension.

Table 1 Heat treatment regimens of experimental material

\begin{tabular}{|c|c|c|}
\hline Sample identification & $\begin{array}{c}\text { Sub-zero temperature } \\
\left({ }^{\circ} \mathbf{C}\right)\end{array}$ & $\begin{array}{c}\text { Tempering temperature } \\
\left({ }^{\circ} \mathbf{C}\right)\end{array}$ \\
\hline W1 & -75 & 170 \\
\hline P1 & -140 & 170 \\
\hline H2 & -196 & 170 \\
\hline W16 & -75 & 530 \\
\hline P16 & -140 & 530 \\
\hline H12 & -196 & 530 \\
\hline
\end{tabular}

\subsection{Hardness tests}

The hardness measurements were carried out using Vickers hardness tester according to ASTM E384-17. Each hardness test was done 5 times and the mean of the obtained hardness values was taken. The average hardness values and standard deviations are shown in Table 2. 
Table 2 Measured hardness values of experimental material

\begin{tabular}{|c|c|c|}
\hline Sample identification & Avg. HV10 & Std. Dev \\
\hline W1 & 910 & 3 \\
\hline P1 & 905 & 9 \\
\hline H2 & 913 & 4 \\
\hline W16 & 743 & 3 \\
\hline P16 & 729 & 6 \\
\hline H12 & 723 & 4 \\
\hline
\end{tabular}

\subsection{Wear testing}

Dry sliding wear tests have been performed with a CSM pin-on-disc tribometer, according to ASTM standard G99-17 [11]. Sintered alumina $\left(\mathrm{Al}_{2} \mathrm{O}_{3}\right)$ balls with a diameter of $6 \mathrm{~mm}$ having the microhardness of $2450 \mathrm{HV} 0.1$ is used as counterpart. The normal applied load was taken as 1,5 , and $10 \mathrm{~N}$. The tests were carried out at different linear speeds of $6.4 \mathrm{~cm} / \mathrm{s}, 12.8 \mathrm{~cm} / \mathrm{s}$, and $18.85 \mathrm{~cm} / \mathrm{s}$, up to a total sliding distance of $100 \mathrm{~m}$, at room temperature $\left(24^{\circ} \mathrm{C}\right)$.

Wear track width measurements were performed on Olympus DSX 1000 digital light microscope, at standard magnification of 50x. Twelve measurements were made on each track, and the mean values were then calculated. These values were used for further assessment in wear volume calculations. The wear volume $\left(V_{l}\right)$ of samples was calculated from the width of the wear tracks using the Equation 1 [11]:

$V_{l}=2 \pi R\left[\frac{r^{2}}{\sin \left(\frac{d}{2 r}\right)}\right]-\frac{d}{4} \sqrt{4 r^{2}-d^{2}}$

where $R$ is the wear track radius, $d$ is the mean value of wear track width, and $r$ is the radius of the ball counterpart. Wear rate $\left(W_{R}\right)$ was then calculated using classical Archard Law of Wear which can be expressed as in the Equation 2 [8]:

$W_{\mathrm{R}}=K \frac{F_{\mathrm{N}}}{\mathrm{HV}}$

where $W_{R}$ is wear rate (in $\mathrm{mm}^{3} / \mathrm{m}$ ), $\mathrm{K}$ is the wear coefficient, $F_{N}$ is the normal load (in newtons), and $\mathrm{HV}$ is the hardness value of the softer of the materials in contact. According to the Equation 2, the wear rate should decrease with increasing the bulk hardness of the specimens. The results in the current study show general trend of decreasing $W_{R}$ with increasing bulk hardness of the specimens.

\subsection{Design of experiments}

Taguchi design is a very popular tool for process parameter optimization under limited number of experimental runs. The number of experiments will be increased when the number of factors and levels increases. Hence, Taguchi technique uses a special level of significance at $95 \%$ through design of orthogonal arrays, to study the process variations under minimum experiments in order to save time, money, and resources instead of performing all possible combinations of experiments. Taguchi method uses a statistical approach called signalto-noise ratio which takes consideration of both mean and the variability to optimize the process settings. For optimization the quality characteristics of nominal is best (NB), lower the better (LB) and higher the better (HB) were applied in Taguchi method [12]. In this current study up on identifying the control factors, and their levels shown in (Table 3), then the L18 $\left(2^{\wedge 1} 3^{\wedge}\right)$ orthogonal array is used for conducting the experiments. 
Table 3 Factors and their levels for wear test

\begin{tabular}{|c|c|c|c|c|}
\hline Level & $\begin{array}{c}\text { Tempering temp } \\
\left({ }^{\circ} \mathbf{C}\right)\end{array}$ & $\begin{array}{c}\text { Sub-zero temp } \\
\left({ }^{\circ} \mathbf{C}\right)\end{array}$ & $\begin{array}{c}\text { Sliding velocity } \\
(\mathbf{c m} / \mathbf{s})\end{array}$ & $\begin{array}{c}\text { Load } \\
(\mathbf{N})\end{array}$ \\
\hline 1 & 170 & -75 & 6.4 & 1 \\
\hline 2 & 530 & -140 & 12.8 & 5 \\
\hline 3 & & -196 & 18.85 & 10 \\
\hline
\end{tabular}

\section{RESULTS AND DISCUSSION}

The wear tests were done according to the Taguchi's L18 $\left(2^{\wedge 1} 3^{\wedge 3}\right)$ array, and the experimental values of average friction coefficient and specific wear rate and their corresponding $\mathrm{S} / \mathrm{N}$ ratios based upon lower the better-quality characteristic are given in (Table 4). The analysis was carried out in Minitab 19 software.

Table $4 \mathrm{~L} 18$ orthogonal array with average coefficient of friction, wear rate, and $\mathrm{S} / \mathrm{N}$ ratios

\begin{tabular}{|c|c|c|c|c|c|c|c|c|}
\hline Run & $\begin{array}{c}\mathbf{T T} \\
\left({ }^{\circ} \mathbf{C}\right)\end{array}$ & $\begin{array}{c}\mathbf{S Z T} \\
\left({ }^{\circ} \mathbf{C}\right)\end{array}$ & $\begin{array}{c}\mathbf{S v} \\
(\mathbf{c m} / \mathbf{s})\end{array}$ & $\begin{array}{c}\mathbf{L} \\
(\mathbf{N})\end{array}$ & $\mathbf{C o F}$ & $\begin{array}{c}\mathbf{S} / \mathbf{N} \text { ratio } \\
(\mathbf{d b})\end{array}$ & $\begin{array}{c}\mathbf{W}_{\mathbf{R}} \\
\left(\mathbf{m m}^{\mathbf{3}} / \mathbf{m}\right)\end{array}$ & $\begin{array}{c}\mathbf{S} / \mathbf{N} \text { ratio } \\
(\mathbf{d b})\end{array}$ \\
\hline 1 & 170 & -75 & 6.4 & 1 & 0.820 & 1.724 & 0.472 & 6.521 \\
\hline 2 & 170 & -75 & 12.8 & 5 & 0.712 & 2.950 & 0.967 & 0.293 \\
\hline 3 & 170 & -75 & 18.85 & 10 & 0.637 & 3.917 & 2.014 & -6.081 \\
\hline 4 & 170 & -140 & 6.4 & 1 & 0.833 & 1.587 & 0.278 & 11.121 \\
\hline 5 & 170 & -140 & 12.8 & 5 & 0.713 & 2.938 & 1.063 & -0.532 \\
\hline 6 & 170 & -140 & 18.85 & 10 & 0.613 & 4.251 & 1.579 & -3.965 \\
\hline 7 & 170 & -196 & 6.4 & 5 & 0.696 & 3.148 & 0.330 & 9.621 \\
\hline 8 & 170 & -196 & 12.8 & 10 & 0.660 & 3.609 & 1.902 & -5.585 \\
\hline 9 & 170 & -196 & 18.85 & 1 & 0.770 & 2.270 & 0.463 & 6.689 \\
\hline 10 & 530 & -75 & 6.4 & 10 & 0.753 & 2.464 & 2.972 & -9.462 \\
\hline 11 & 530 & -75 & 12.8 & 1 & 0.840 & 1.514 & 0.553 & 5.145 \\
\hline 12 & 530 & -75 & 18.85 & 5 & 0.748 & 2.522 & 1.476 & -3.379 \\
\hline 13 & 530 & -140 & 6.4 & 5 & 0.708 & 2.999 & 1.186 & -1.483 \\
\hline 14 & 530 & -140 & 12.8 & 10 & 0.749 & 2.510 & 3.224 & -10.168 \\
\hline 15 & 530 & -140 & 18.85 & 1 & 0.776 & 2.203 & 0.363 & 8.798 \\
\hline 16 & 530 & -196 & 6.4 & 10 & 0.776 & 2.203 & 3.226 & -10.175 \\
\hline 17 & 530 & -196 & 12.8 & 1 & 0.815 & 1.777 & 0.445 & 7.042 \\
\hline 18 & 530 & -196 & 18.85 & 5 & 0.696 & 3.148 & 1.713 & -4.677 \\
\hline
\end{tabular}

TT: tempering temperature; SZT: sub-zero temperature; Sv: sliding velocity; L: Load; CoF: coefficient of friction; $W_{\mathrm{R}}$ : wear rate

\section{1. $\mathrm{S} / \mathrm{N}$ ratio analysis}

The response table for average friction coefficient and specific wear rate is presented in Table 5, and Table 6 . To obtain better performance, the setting for optimum control factors can be attained by taking the highest values of $\mathrm{S} / \mathrm{N}$ ratios. In Table 5 and Table 6 values in bold represent the largest values of $\mathrm{S} / \mathrm{N}$ ratios. From Table 5 it is observed that the grouping of factors; Tempering temperature: $170^{\circ} \mathrm{C}$ (level 1), Sub-zero temperature: $-140^{\circ} \mathrm{C}$ (level 2), Sliding velocity: $18.85 \mathrm{~cm} / \mathrm{s}$ (level 3), and Load: $10 \mathrm{~N}$ (level 3) gives minimum average friction coefficient, and from (Table 6), it can be perceived that the grouping of factors; Tempering temperature: $170^{\circ} \mathrm{C}$ (level 1), Sub-zero temperature: $-140^{\circ} \mathrm{C}$ (level 2), Sliding velocity: $6.4 \mathrm{~cm} / \mathrm{s}$ (level 1), and 
Load: $1 \mathrm{~N}$ (level 1) gives minimum wear rate. Moreover, from (Table 5) it is perceived that load is the most important parameter that affects the friction coefficient followed by sliding velocity, tempering temperature, and sub-zero temperature. Further, from (Table 6) it can also be perceived that load is the most important parameter that affects the wear rate followed by tempering temperature, sub-zero temperature, and sliding velocity.

Table 5 Response table for $\mathrm{S} / \mathrm{N}$ ratios of average coefficient of friction (Smaller is better)

\begin{tabular}{|c|c|c|c|c|}
\hline Level & $\begin{array}{c}\text { Tempering temp } \\
\left({ }^{\circ} \mathbf{C}\right)\end{array}$ & $\begin{array}{c}\text { Sub-zero temp } \\
\left({ }^{\circ} \mathbf{C}\right)\end{array}$ & $\begin{array}{c}\text { Sliding velocity } \\
(\mathbf{c m} / \mathbf{s})\end{array}$ & $\begin{array}{c}\text { Load } \\
(\mathbf{N})\end{array}$ \\
\hline 1 & 2.933 & 2.692 & 2.354 & 1.846 \\
\hline 2 & 2.371 & 2.748 & 2.550 & 2.951 \\
\hline 3 & & 2.515 & 3.052 & 3.159 \\
\hline Delta & 0.562 & 0.233 & 0.698 & 1.313 \\
\hline Rank & 3 & 4 & 2 & 1 \\
\hline
\end{tabular}

Table 6 Response table for $\mathrm{S} / \mathrm{N}$ ratios of wear rate (Smaller is better)

\begin{tabular}{|c|c|c|c|c|}
\hline Level & $\begin{array}{c}\text { Tempering temp } \\
\left({ }^{\circ} \mathbf{C}\right)\end{array}$ & $\begin{array}{c}\text { Sub-zero temp } \\
\left({ }^{\circ} \mathbf{C}\right)\end{array}$ & $\begin{array}{c}\text { Sliding velocity } \\
(\mathbf{c m} / \mathbf{s})\end{array}$ & $\begin{array}{c}\text { Load } \\
(\mathbf{N})\end{array}$ \\
\hline 1 & $\mathbf{2 . 0 0 9}$ & 0.485 & $\mathbf{1 . 0 2 4}$ & $\mathbf{7 . 5 5 2}$ \\
\hline 2 & -2.040 & $\mathbf{0 . 6 2 8}$ & -0.634 & -0.026 \\
\hline 3 & & -1.160 & -0.435 & -7.572 \\
\hline Delta & 4.049 & 1.788 & 1.658 & 15.125 \\
\hline Rank & 2 & 3 & 4 & 1 \\
\hline
\end{tabular}

\subsection{Analysis of variance (ANOVA)}

ANOVA is a statistical analysis performed along with the Taguchi technique to identify the significant factors and their influence on the response parameter. The percentage contribution of each input parameter on the output response can be estimated by ANOVA. ANOVA analysis was executed at $95 \%$ confidence level and at a $5 \%$ significance level [12]. The results of ANOVA test for average friction coefficient, and specific wear rate are shown in (Table 7 and Table 8). From Table 7 it is evident that the load is the most significant factor influencing the average friction coefficient. The percentage contribution of load towards friction coefficient is $56.75 \%$ followed by sliding velocity $(14.75 \%)$, and tempering temperature $(13.47 \%)$. From Table 8 it is conclusive that the load is the most significant factor to specific wear rate. The percentage contribution of load towards specific wear rate is $(78.60 \%)$ followed by tempering temperature $(8.45 \%)$.

Table 7 Analysis of Variance for S/N Ratios for average coefficient of friction

\begin{tabular}{|c|c|c|c|c|c|c|c|}
\hline Source & DF & Seq SS & Adj SS & Adj MS & F & P & \%C \\
\hline TT & 1 & 1.419 & 1.419 & 1.419 & 10.10 & 0.010 & 13.47 \\
\hline SZT & 2 & 0.177 & 0.177 & 0.088 & 0.63 & 0.552 & 1.68 \\
\hline SV & 2 & 1.553 & 1.553 & 0.776 & 5.53 & 0.024 & 14.75 \\
\hline L & 2 & 5.978 & 5.978 & 2.989 & 21.27 & 0.000 & 56.75 \\
\hline Residual Error & 10 & 1.405 & 1.405 & 0.140 & & & \\
\hline Total & 17 & 10.533 & & & & & \\
\hline
\end{tabular}

DF: degrees of freedom; Seq SS: sequential sum of squares; Adj SS: adjusted sum of squares; Adj MS: adjusted mean squares; C: $\%$ contribution 
Table 8 Analysis of Variance for S/N Ratios for wear rate

\begin{tabular}{|c|c|c|c|c|c|c|c|}
\hline Source & DF & Seq SS & Adj SS & Adj MS & F & P & \%C \\
\hline TT & 1 & 73.775 & 73.775 & 73.775 & 8.08 & 0.017 & 8.45 \\
\hline SZT & 2 & 11.862 & 11.862 & 5.931 & 0.65 & 0.543 & 1.36 \\
\hline SV & 2 & 9.843 & 9.843 & 4.922 & 0.54 & 0.600 & 1.13 \\
\hline L & 2 & 686.335 & 686.335 & 343.167 & 37.56 & 0.000 & 78.60 \\
\hline Residual Error & 10 & 91.362 & 91.362 & 9.136 & & & \\
\hline Total & 17 & 873.176 & & & & & \\
\hline
\end{tabular}

DF: degrees of freedom; Seq SS: sequential sum of squares; Adj SS: adjusted sum of squares; Adj MS: adjusted mean squares; C: \% contribution

\subsection{Taguchi confirmation experiment}

Also, Taguchi confirmation tests are performed to validate the experimental results and to evaluate the accuracy of the analysis. The comparison of the Taguchi prediction values and the actual experimental values are shown in (Table 9).

Table 9 Confirmation experiments

\begin{tabular}{|c|c|c|c|c|c|c|c|}
\hline Response & $\begin{array}{c}\text { TT } \\
\left({ }^{\circ} \mathbf{C}\right)\end{array}$ & $\begin{array}{c}\text { SZT } \\
\left({ }^{\circ} \mathbf{C}\right)\end{array}$ & $\begin{array}{c}\text { SV } \\
(\mathbf{c m} / \mathbf{s})\end{array}$ & $\begin{array}{c}\mathbf{L} \\
(\mathbf{N})\end{array}$ & Prediction & Experiment & $\%$ Error \\
\hline $\mathrm{CoF}$ & 170 & -140 & 18.85 & 10 & 3.935 & 4.250 & 7 \\
\hline $\mathrm{W}_{\mathrm{R}}$ & 170 & -140 & 6.4 & 1 & 11.260 & 11.120 & 1 \\
\hline
\end{tabular}

Error values less than $20 \%$ are considered as reliable for confirming the model confidence [13]. It can be observed that for both average friction coefficient and specific wear rate the error values are less than $20 \%$, hence from Taguchi approach the results are in good agreement with both experimental and analytical methods.

\section{CONCLUSION}

Taguchi design of experiment technique is successfully utilized to analyse and optimize the friction coefficient and wear rate of PM Vanadis 6 steel. The following conclusions can be drawn from the above analysis.

- $\quad$ For mean friction coefficient, the optimum settings are: tempering temperature $\left(170^{\circ} \mathrm{C}\right)$, sub-zero temperature $\left(-140^{\circ} \mathrm{C}\right)$, sliding velocity $(18.85 \mathrm{~cm} / \mathrm{s})$, and normal load $(10 \mathrm{~N})$.

- Load $(56.75 \%)$ is the main significant factor for mean friction coefficient which is having highest contribution, followed by sliding velocity (14.75\%), and tempering temperature (13.47\%).

- $\quad$ For wear rate, the optimum settings are: tempering temperature $\left(170^{\circ} \mathrm{C}\right)$, sub-zero temperature ($\left.140^{\circ} \mathrm{C}\right)$, sliding velocity $(6.4 \mathrm{~cm} / \mathrm{s})$, and normal load $(1 \mathrm{~N})$.

- $\quad$ Load $(78.60 \%)$ is also the main significant factor for wear rate which is having highest contribution, followed by tempering temperature $(8.45 \%)$.

\section{REFERENCES}

[1] JURČI, P., DOMÁNKOVÁ, M., HUDÁKOVÁ, M., PTAČINOVÁ, J., PAŠÁK, M., PALČEK, P. Characterization of microstructure and tempering response of conventionally quenched, short- and long-time sub-zero treated PM Vanadis 6 ledeburitic tool steel. Materials Characterization. 2017, vol. 134, pp. 398-415.

[2] JURČl, P. Cr-V ledeburitic cold-work tool steels. Materiali in Tehnologije. 2011, vol. 45, pp. 383-394. 
[3] BÍLEK, P., SOBOTOVÁ, J., JURČI, P. Evaluation of the microstructural changes in Cr-V ledeburitic tool steels depending on the austenitization temperature. Materiali in Tehnologije. 2011, vol. 45, pp. 489-493.

[4] DAS, D., DUTTA, A. K., RAY, K. K. Influence of varied cryotreatment on the wear behavior of AISI D2 steel. Wear. 2009, vol. 266, pp. 297-309.

[5] AKHBARIZADEH, A., JAVADPOUR, S., AMINI, K. Investigating the effect of electric current flow on the wear behavior of 1.2080 tool steel during the deep cryogenic heat treatment. Materials \& Design. 2013, vol. 45, pp. 103-109.

[6] DAS, D., DUTTA, A. K., RAY, K. K. Optimization of the duration of cryogenic processing to maximize wear resistance of AISI D2 steel. Cryogenics. 2009, vol. 49, pp. 176-184.

[7] MENG, F., TAGASHIRA, K., AZUMA, R., SOHMA, H. Role of eta-carbide precipitations in the wear resistance improvements of Fe-12Cr-Mo-V-1.4C tool steel by cryogenic treatment. ISIJ International. 1994, vol. 34, pp. 205210.

[8] DAS, D., DUTTA, A. K., RAY, K. K. Sub-zero treatments of AISI D2 steel: part II. wear behavior. Material Science and Engineering: A. 2010, vol. 527, pp. 2194-2206.

[9] SOBOTOVÁ, J., JURČI, P., DLOUHY, I. The effect of subzero treatment on microstructure, fracture toughness, and wear resistance of Vanadis 6 tool steel. Material Science and Engineering: A. 2016, vol. 652, pp.192-204.

[10] JURČI, P., DLOUHÝ, I., PRIKNEROVÁ, P., MRŠTNÝ, Z. Effect of sub-zero treatment temperatures on hardness, flexural strength, and fracture toughness of Vanadis 6 ledeburitic die steel. Metals. 2018, vol. 8, pp. 1047.

[11] ASTM G99-17. Standard test method for wear testing with a pin-on-disk apparatus. West Conshohocken, PA, USA: ASTM International, 2017.

[12] DATTA, S., BANDYOPADHYAY, A., PAL, P. K. Grey-based taguchi method for optimization of bead geometry in submerged arc bead-on-plate welding. The International Journal of Advanced Manufacturing Technology. 2008, vol. 39, pp. 1136-1143.

[13] PRAJAPATI, P. K., KUMAR, S., SINGH, K. K. Optimization of tribological behaviour of CFRP composites under dry sliding condition using taguchi method. Materials Today: Proceedings. 2020, vol. 21, pp. 1320-1329. 